\title{
Correction to: Genomic diversity and population structure of the Leonberger dog breed
}

\author{
Anna Letko ${ }^{*}$, Katie M. Minor ${ }^{2}$, Vidhya Jagannathan ${ }^{1}$, Franz R. Seefried ${ }^{3}$, James R. Mickelson ${ }^{2}$, Pieter Oliehoek ${ }^{4}$ \\ and Cord Drögemüller ${ }^{1}$
}

\section{Correction to: Genet Sel Evol (2020) 52:61}

https://doi.org/10.1186/s12711-020-00581-3

After publication of the original article [1], the authors noticed a typesetting error in the hyper-linking of the additional files. The additional files have been relinked and can be accessed via the original article.

\section{Author details}

${ }^{1}$ Institute of Genetics, Vetsuisse Faculty, University of Bern, 3012 Bern, Switzerland. ${ }^{2}$ Department of Veterinary and Biomedical Sciences, College of Veterinary Medicine, University of Minnesota, St. Paul, MN 55108, USA. ${ }^{3}$ Qualitas AG, 6300 Zug, Switzerland. ${ }^{4}$ Dogs Global, 6871 EK Renkum, The Netherlands.

\section{Reference}

1. Letko A, Minor KM, Jagannathan V, Seefried FR, Mickelson JR, Oliehoek P, Drögemüller C. Genomic diversity and population structure of the Leonberger dog breed. Genet Sel Evol. 2020;52:61. https://doi.org/10.1186/ s12711-020-00581-3.

\section{Publisher's Note}

Springer Nature remains neutral with regard to jurisdictional claims in published maps and institutional affiliations.

Published online: 18 November 2020

The original article can be found online at https://doi.org/10.1186/s1271 $1-020-00581-3$

*Correspondence: anna.letko@vetsuisse.unibe.ch

${ }^{1}$ Institute of Genetics, Vetsuisse Faculty, University of Bern, 3012 Bern, Switzerland

Full list of author information is available at the end of the article

(c) The Author(s) 2020. This article is licensed under a Creative Commons Attribution 4.0 International License, which permits use, sharing, adaptation, distribution and reproduction in any medium or format, as long as you give appropriate credit to the original author(s) and the source, provide a link to the Creative Commons licence, and indicate if changes were made. The images or other third party material in this article are included in the article's Creative Commons licence, unless indicated otherwise in a credit line to the material. If material is not included in the article's Creative Commons licence and your intended use is not permitted by statutory regulation or exceeds the permitted use, you will need to obtain permission directly from the copyright holder. To view a copy of this licence, visit http://creativecommons.org/licenses/by/4.0/. The Creative Commons Public Domain Dedication waiver (http://creativecommons.org/publicdomain/zero/1.0/) applies to the data made available in this article, unless otherwise stated in a credit line to the data. 